ISSN 1112-9867

http://www.jfas.info

\title{
EFFECT OF TORREFACTION ON OIL PALM EMPTY FRUIT BUNCH PELLETIZATION
}

M. I. Ahmad ${ }^{1,3,}$, W. N. K. W. Jusoh ${ }^{5}$, Z. I. Rizman ${ }^{2}$, M. S. M. Rasat ${ }^{1}$, Z. A. Z. Alauddin ${ }^{3}$, S. N. M. Soid ${ }^{4}$, M. S. A. Aziz ${ }^{3}$, M. Mohamed ${ }^{1}$ and M. F. M. Amin ${ }^{5}$

${ }^{1}$ Faculty of Bioengineering and Technology, Universiti Malaysia Kelantan, 17600 Jeli, Kelantan, Malaysia

${ }^{2}$ Faculty of Electrical Engineering, Universiti Teknologi MARA, 23000 Dungun, Terengganu, Malaysia

${ }^{3}$ School of Mechanical Engineering, Universiti Sains Malaysia, 14300 Nibong Tebal, Penang, Malaysia

${ }^{4}$ Academic and Technology Department, Universiti Kuala Lumpur, Malaysian Spanish Institute, 09000 Kulim, Kedah, Malaysia

${ }^{5}$ Faculty of Earth Science, Universiti Malaysia Kelantan, 17600 Jeli, Kelantan, Malaysia

Published online: 10 September 2017

\begin{abstract}
This paper focuses on the properties of raw and torrified pellet from EFB by varying different parameters including energy consumption, moisture adsorption, Meyer hardness test and pellet density. To save storage space and transport costs, it can be compressed into fuel pellets of high physical and energetic density. The pelletizing properties were determined using single pellet press and pellet stability was determined by compression testing.
\end{abstract}

Author Correspondence, e-mail: iqbal.a@umk.edu.my

doi: http://dx.doi.org/10.4314/jfas.v9i3s.66 
Pelletization of raw and torrified empty fruit bunch (EFB) from compression single pellet press (SPP) was investigated to quantify the energy consumption and pellet properties including moisture adsorption, pellet density and Meyer hardness. Energy consumption for torrified EFB pellet were significantly higher than those for raw EFB pellet, while the moisture adsorption rate of torrified EFB pellets increased with increasing the severity of torrefaction.

Keywords: oil palm empty fruit bunch (EFB) torrefaction; pelletization.

\section{INTRODUCTION}

Torrefaction is a pre-treatment process where biomass is heated in the absence of oxygen at low heating rates which is less than $50^{\circ} \mathrm{C} / \mathrm{min}$ to temperatures between $200^{\circ} \mathrm{C}$ and $300^{\circ} \mathrm{C}$ to produce a darkened material with improved chemical and physical properties. The moisture and oxygen-rich volatile materials with low calorific value are driven off will result in a reduction in hydroxyl groups that can form hydrogen bonds with moisture and a greater mass loss to energy loss producing a more energy dense fuel during torrefaction [5]. Torrefaction of biomass accompanies weight loss depends on torrefaction conditions. During torrefaction of biomass, most volatile compounds are removed from biomass vapors and result in a higher energy density. In addition, the advantages of torrefaction include higher calorific value or energy density, lower moisture content and better grinding [3].

Few studies have been published in recent years, focusing on how to make a pellet from different biomass [8] but to the best author knowledge none have studied in detail on how to make a quality pellet from raw and torrified EFB. There were many challenges to utilize the raw biomass due to its characteristic. This is because the raw biomass is usually high in moisture content, low energy density, difficult to store and poor grind ability [2]. It also is bulky and inhomogeneous materials that make it difficult to comminute into small particle [6]. Some studies produced torrified pellets from other biomass such as oil palm mesocarp fiber (PMF). Pelletizing properties of torrified biomass have been analyzed depending on torrefaction conditions [3].The biomass have been milled, dried and mechanically densified during pelletization to enhancing its heating value and burning characteristics [1]. In this 
study, EFB was used to carry out a study on physical and mechanical properties of raw and torrefied pellet. The effects of pellets from raw and torrefaction conditions on the physical properties and mechanical properties from raw and torrefied EFB was successful characterized.

\section{METHODOLOGY}

\subsection{Sample Preparation of Raw and Torrified EFB}

The raw sample weighed of $200 \mathrm{~g}$ was dried inside the oven for about two hours at $105^{\circ} \mathrm{C}$ at 24 hours. This method is to remove the whole moisture content from the EFB. The preparation for sample of raw, the sample were grinded and sieved at 3 sizes which is $250 \mu \mathrm{m}$, $500 \mu \mathrm{m}$ and $750 \mu \mathrm{m}$ while for the preparation of torrified sample, $500 \mu \mathrm{m}$ of EFB was required in this process. After that, torrefaction temperature of the sample that put inside the microwave [10] were $200^{\circ} \mathrm{C}, 225^{\circ} \mathrm{C}, 250^{\circ} \mathrm{C}, 275^{\circ} \mathrm{C}$ and $300^{\circ} \mathrm{C}$ and then the residence time that setting in this process at 3 time which is 20,40 and 60 minutes with continuous purge of $30 \mathrm{ml} / \mathrm{min}$ nitrogen gas. The selected power that was used in this process is $100,230,385,540$ and $700 \mathrm{~W} .500 \mu \mathrm{m}$ and $15 \mathrm{~g}$ of EFB that was required while conducting this process to have the effect [11] of heating rate on different power, temperature on power selection, magnetron on power selection, power on fractional torrefied biomass and temperature on mass loss was recorded to choose the best selected power. The main reason to choose the best selected power because of the best power will produced the torrefied material. Besides that, it also to proven either this biomass can be used as renewable energy. The schematic diagram of pellet mold based as shown Fig. 1. 


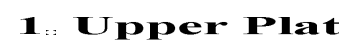

2

Midale Plat

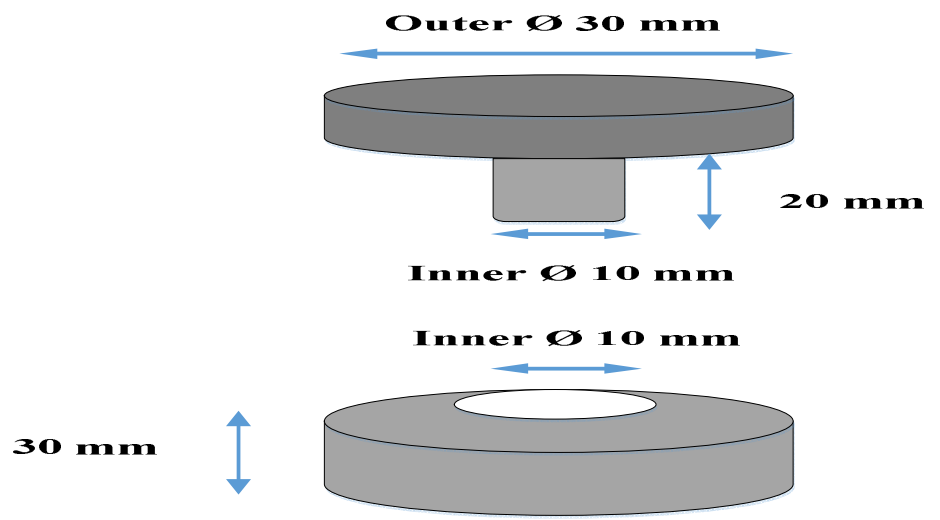

3.: Lower Plat

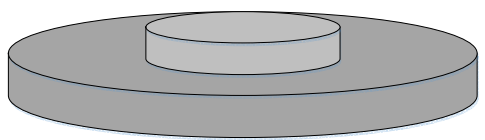

Fig.1. Schematic diagram of pellet mold

\subsection{Pelletization of Raw and Torrefied Pellet and Product Analysis}

For the preparation of pellet from raw EFB, the biomass was loaded in pellet mold, not exceeding $1 \mathrm{~g}$ per layer which is at 3 different size, $250 \mu \mathrm{m}, 500 \mu \mathrm{m}$ and $750 \mu \mathrm{m}$ for $0.60 \mathrm{~g}$, $0.55 \mathrm{~g}$ and $0.50 \mathrm{~g}$ respectively. While for the preparation of pellet from torrefied EFB, $500 \mu \mathrm{m}$ of EFB size was loaded in pellet mold in $0.70 \mathrm{~g}$ with $10 \%$ of glycerol as a binder agent for different temperature and residence time which is $200^{\circ} \mathrm{C}, 250^{\circ} \mathrm{C}$ and $300^{\circ} \mathrm{C}$ and $20,40,60$ minutes. When the all sample was prepared, the process of compression pellet was conducted. The sample was compressed with a maximum pressure of $200 \mathrm{MPa}$ at rate of $5 \mathrm{~mm} / \mathrm{min}$ using a Universal Testing Machine (UTM), equipped with a maximum $5 \mathrm{kN}$ load cell and an electronic data collection system. And then, the pressure was released after 5 seconds, the piston removed and a new amount of sample is load and compress until the pellet had desired dimensions. The sample was pressed by applying a force $1 \mathrm{kN}-5 \mathrm{kN}$ for raw sample and then for torrefied sample $1 \mathrm{kN}$ and $5 \mathrm{kN}$.

In this study, the raw and torrified pellet were made and used to determine the physical and mechanical properties of pellet. The Meyer hardness against compression from a static indentation test was measured. When a force is applied to the pellet, the pellet will be deformed. The Meyer hardness $\left(\mathrm{H}_{\mathrm{m}}\right)$ defined as the static indentation hardness was 
determined from the applied force, probe diameter and indentation depth as Equation (1).

$$
\mathrm{H}_{\mathrm{m}}=\mathrm{F} /\left[\pi\left(\mathrm{Dh}-\mathrm{h}^{2}\right)\right]
$$

where $\mathrm{h}$ is indentation depth; $\mathrm{F}$ is the force ; and $\mathrm{D}$ is the diameter of rod. Meyer hardness was reflects the resistance of the solid object to various kinds of permanent shape changes when an axial force is applied. To calculate the energy consumption, forces and displacement was recorded to form the pellets. The decomposition of hemicellulose and lignin reduced the plasticity of sawdust, contributes to the increased energy consumption during the compression and extrusion. The single pellet density was calculated from measured mass and volume of individual pellet. The strength of pellets was measured $24 \mathrm{~h}$ after production. Before the strength measurement, dimensions (length and diameter) and mass of each pellet was measured using weighing balance and for the volume was measured by vernier calipers to calculate pellet density. The density or more precisely the volumetric mass density of a substance is its mass per unit volume. For moisture adsorption testing, the sample was dried in an oven at $30^{\circ} \mathrm{C}$ for 2 hours. After that, the sample was placed in climatic chamber at $30^{\circ} \mathrm{C}$ and $90 \%$ of relative humidity. After moisture absorption in climatic chamber, the moisture uptake was measured as the weight difference between the initial dry weight and the equilibrated weight.

\section{RESULTS AND DISCUSSION}

\subsection{Appearance Study of Raw and Torrefied EFB Pellets}

Table 1 shows the appearance of raw pellet while the appearance of torrefied pellet was shown in Table 2. The pressure force that have been used for the raw pellet, $1 \mathrm{kN}$ until $5 \mathrm{kN}$ while for the torrefied pellet, only $1 \mathrm{kN}$ and $5 \mathrm{kN}$. For pelletizing torrefied pellet, glycerol have been used and also act as binder agent. 
Table 1. The appearance of raw EFB pellets on different force

\begin{tabular}{|c|c|c|c|c|c|}
\hline \multirow[b]{2}{*}{ Sample } & \multicolumn{5}{|c|}{ Pellet } \\
\hline & $1 \mathrm{kN}$ & $2 \mathrm{kN}$ & $3 \mathrm{kN}$ & $4 \mathrm{kN}$ & $5 \mathrm{kN}$ \\
\hline & & & & & \\
\hline $500 \mathrm{mic}$ & & & & & \\
\hline
\end{tabular}

Table 2. The appearance of torrefied EFB pellets on different force

PELLET (with Glycerol 10\% as Binder Agent)

Sample

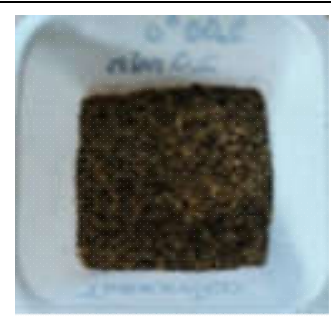

$200^{\circ} \mathrm{C}(20 \mathrm{~min})$

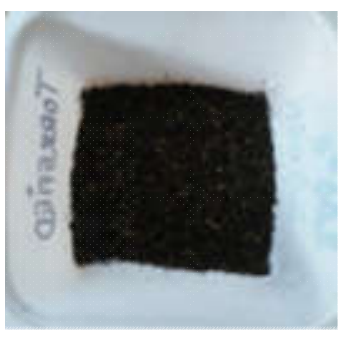

$250^{\circ} \mathrm{C}(20 \mathrm{~min})$

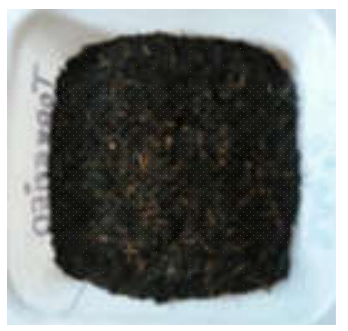

$300^{\circ} \mathrm{C}(20 \mathrm{~min})$
$1 \mathrm{kN}$
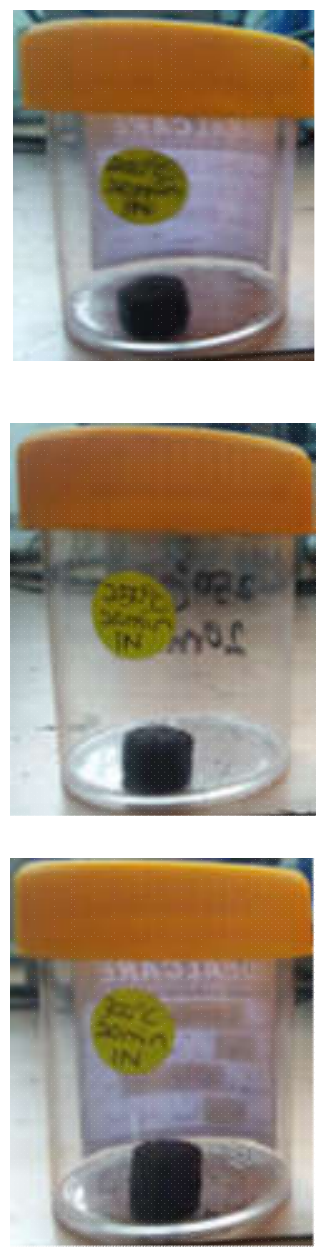

$5 \mathrm{kN}$
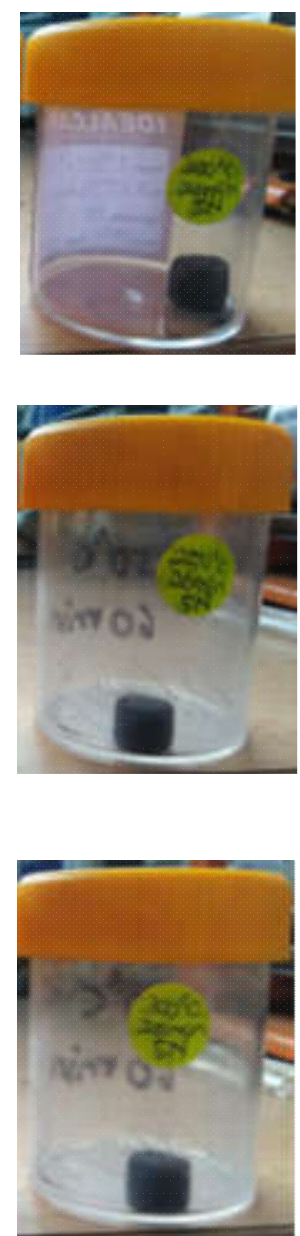


\subsection{Meyer Hardness}

The average Meyer hardness was measured for selected pellets, with average results shown in

Fig. 1a and b. Fig. 1a shows that the hardness of raw sample decreased with increasing of particle sizes. The highest hardness of raw sample is at $250 \mathrm{mic}$ with force $5 \mathrm{kN}$ which is $10.77 \mathrm{~N} / \mathrm{mm}^{2}$, while the lowest hardness is at the sizes $750 \mathrm{mic}$ with force $1 \mathrm{kN}$ which is $2.20 \mathrm{~N} / \mathrm{mm}^{2}$. Fig. $1 \mathrm{~b}$ shows that the hardness of torrefied sample decreased with the increasing of degree of torrefaction and residence time. The highest hardness of torrefied sample is at $200^{\circ} \mathrm{C}$ with the residence time $20 \mathrm{~min}$ and $5 \mathrm{kN}$ force which is $9.71 \mathrm{~N} / \mathrm{mm}^{2}$, while the lowest hardness is at $300^{\circ} \mathrm{C}$ with the $60 \mathrm{~min}$ residence time and different force, $1 \mathrm{kN}$ which is $1.80 \mathrm{~N} / \mathrm{mm}^{2}$. For comparison, the hardness of torrefied sample is lower than raw sample. Due to the amount of available hydrogen bonding sites is reduced during torrefaction. So, the strength of torrefied pellets is lowered compared to pellets made from untreated sawdust as shown in previous research [9].

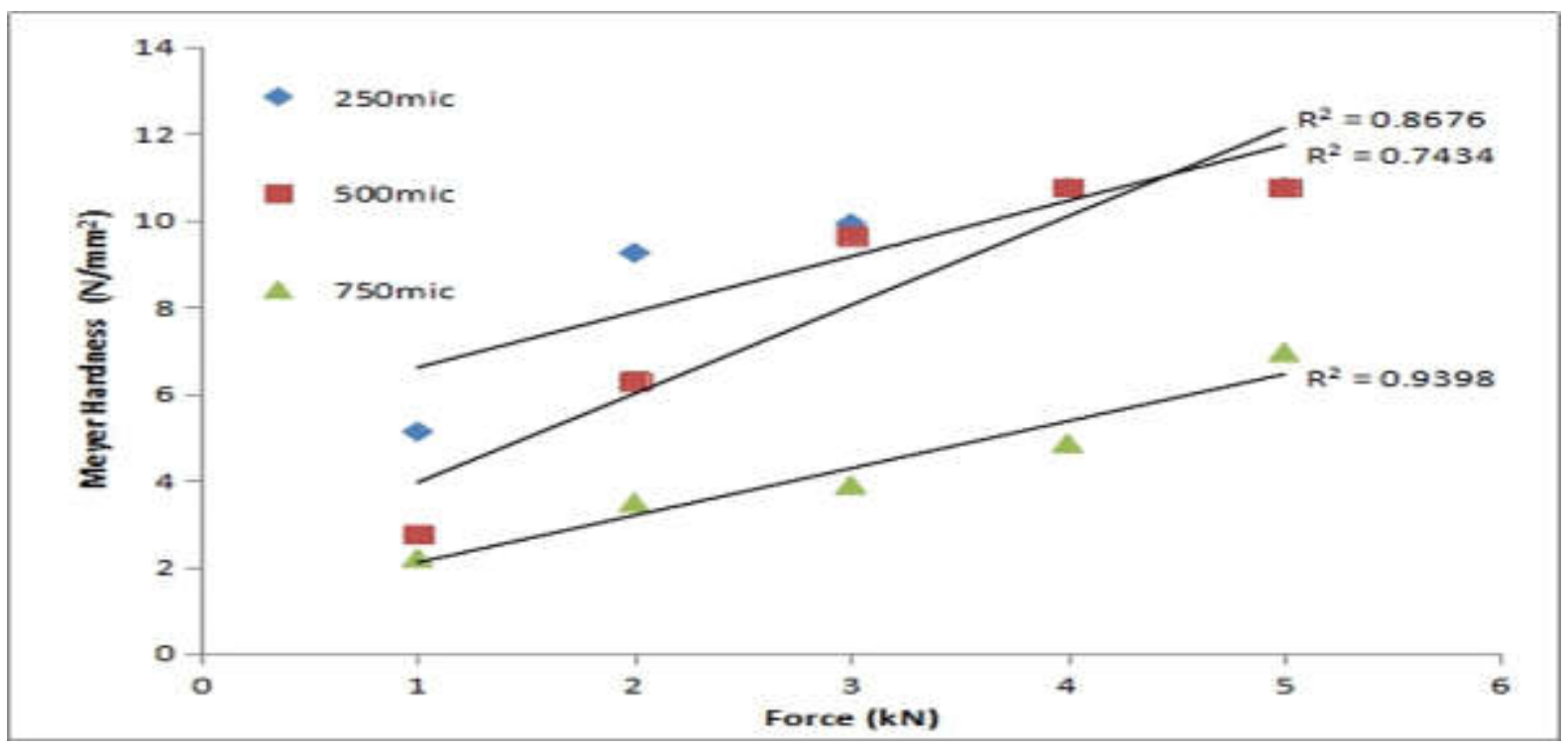

Fig.1a. Meyer hardness of raw EFB pellets 


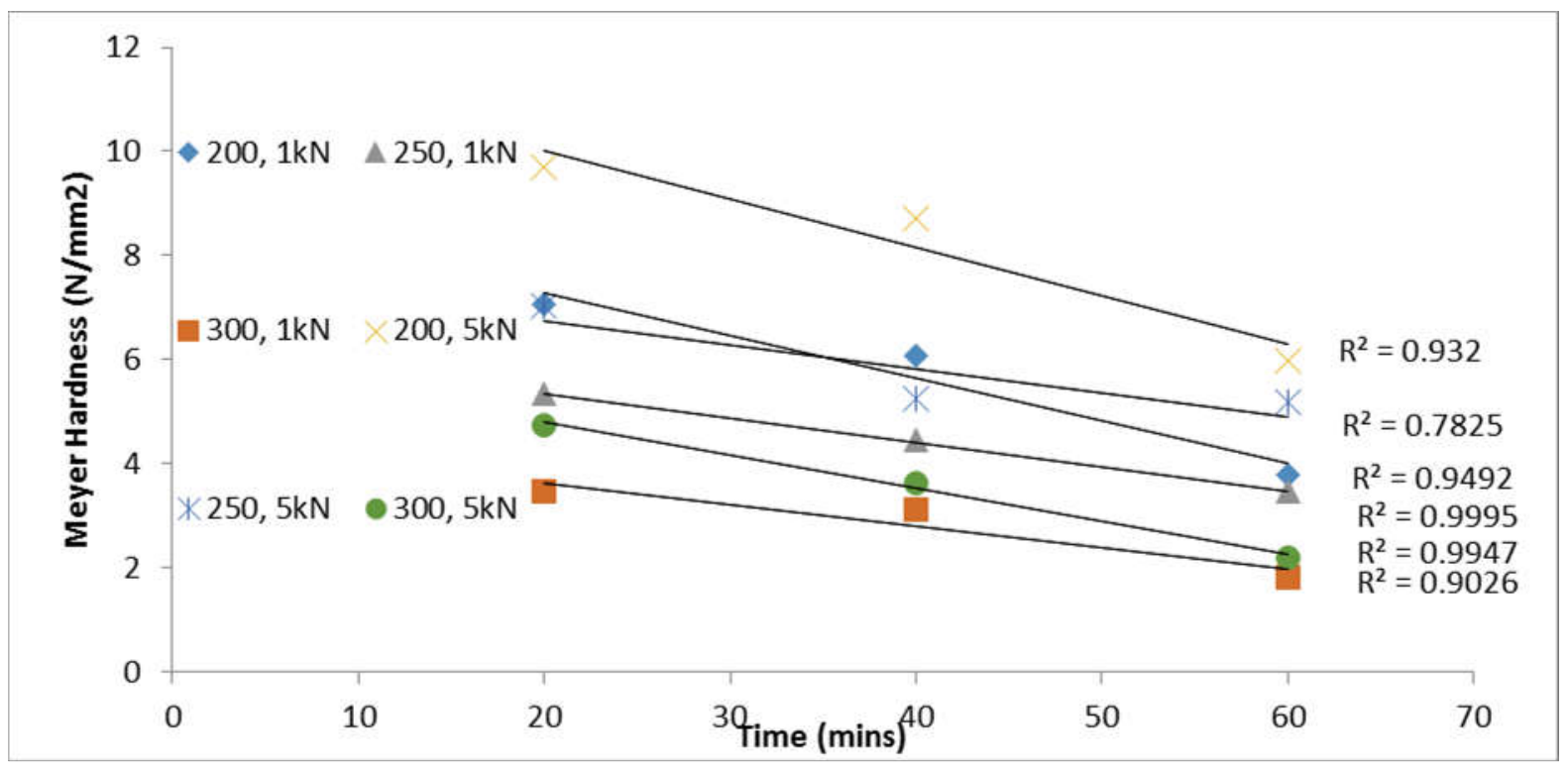

Fig.1b. Meyer hardness of torrified EFB pellets

\subsection{Energy Consumption}

Energy consumption associated with compression of single pellet for raw and torrefied EFB pellets are presented in Fig. $2 \mathrm{a}$ and $\mathrm{b}$ respectively as a function of force, torrefaction temperature and residence time. The trend data analysis of raw and torrefied EFB pellets in Fig. $2 \mathrm{a}$ and $\mathrm{b}$ shows increased trend with wide ranges of sizes and densities. Higher energy input is needed to densify the torrefied EFB pellets than raw EFB pellets, and the energy requirement increasesd with increasing the degree of torrefaction. Early study showed the torrefied EFB could not be pelletized without glycerol, compared to pelletized raw EFB. Higher die temperature is needed to make a rigid torrified pellets. Fig. 2a shows the highest energy consumption of raw sample at $750 \mathrm{mic}$ and $5 \mathrm{kN}$ force which is $80.68 \mathrm{~kJ} / \mathrm{kg}$, while the lowest energy consumption of raw sample at $250 \mathrm{mic}$ and $1 \mathrm{kN}$ force which is $11.24 \mathrm{~kJ} / \mathrm{kg}$. Fig. $2 \mathrm{~b}$ also shows the highest energy consumption of torrefied pellet at $300^{\circ} \mathrm{C}$ with the residence time $60 \mathrm{~min}$ and $5 \mathrm{kN}$ force which is $97.01 \mathrm{~kJ} / \mathrm{kg}$, while the lowest energy consumption of torrefied pellet at $200^{\circ} \mathrm{C}$ with the residence time $20 \mathrm{~min}$ and $1 \mathrm{kN}$ force which is $19.01 \mathrm{~kJ} / \mathrm{kg}$. For comparison, the torrefied sample consume more energy than raw sample to be pelletized the pellet. 


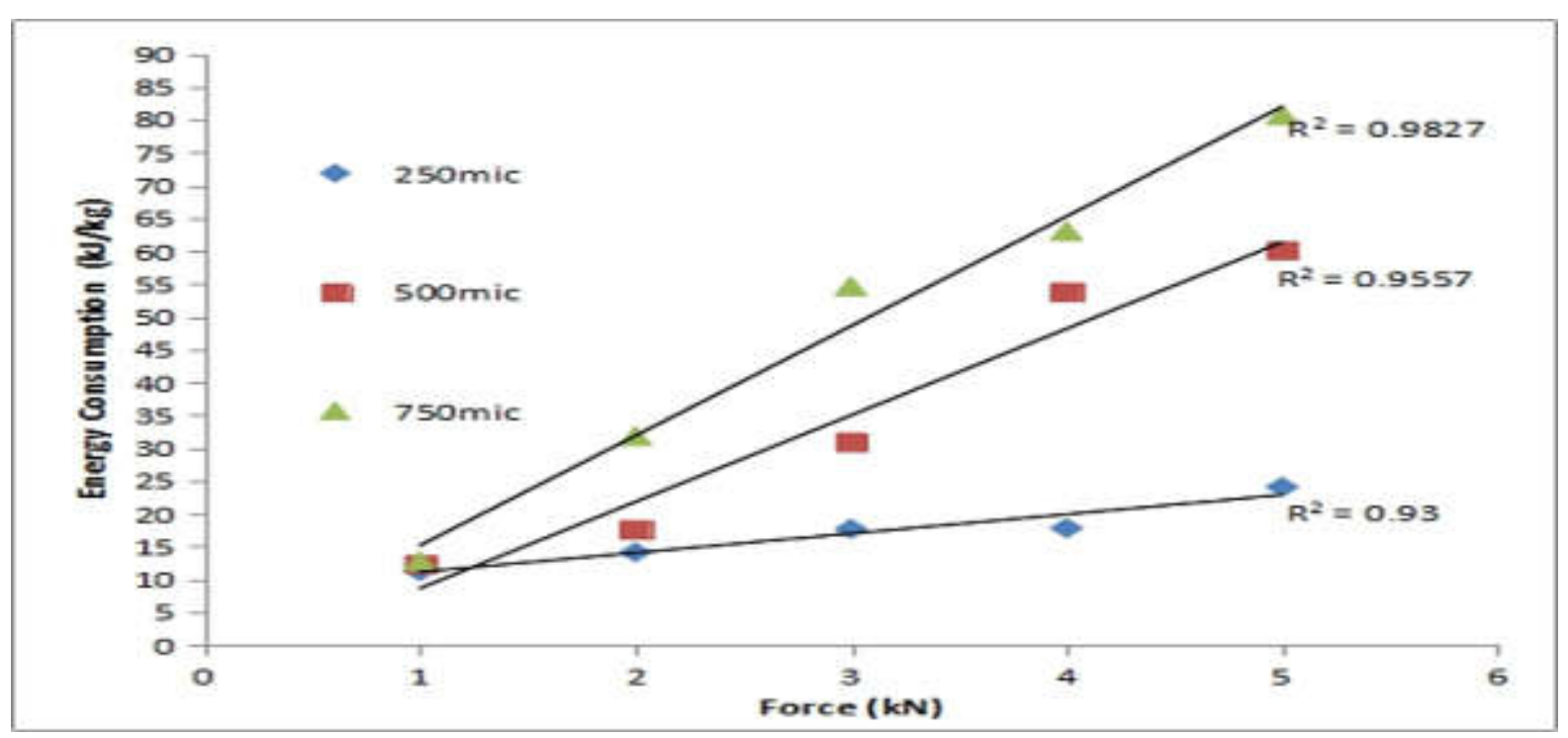

Fig.2a. Effect of energy consumption raw EFB pellets

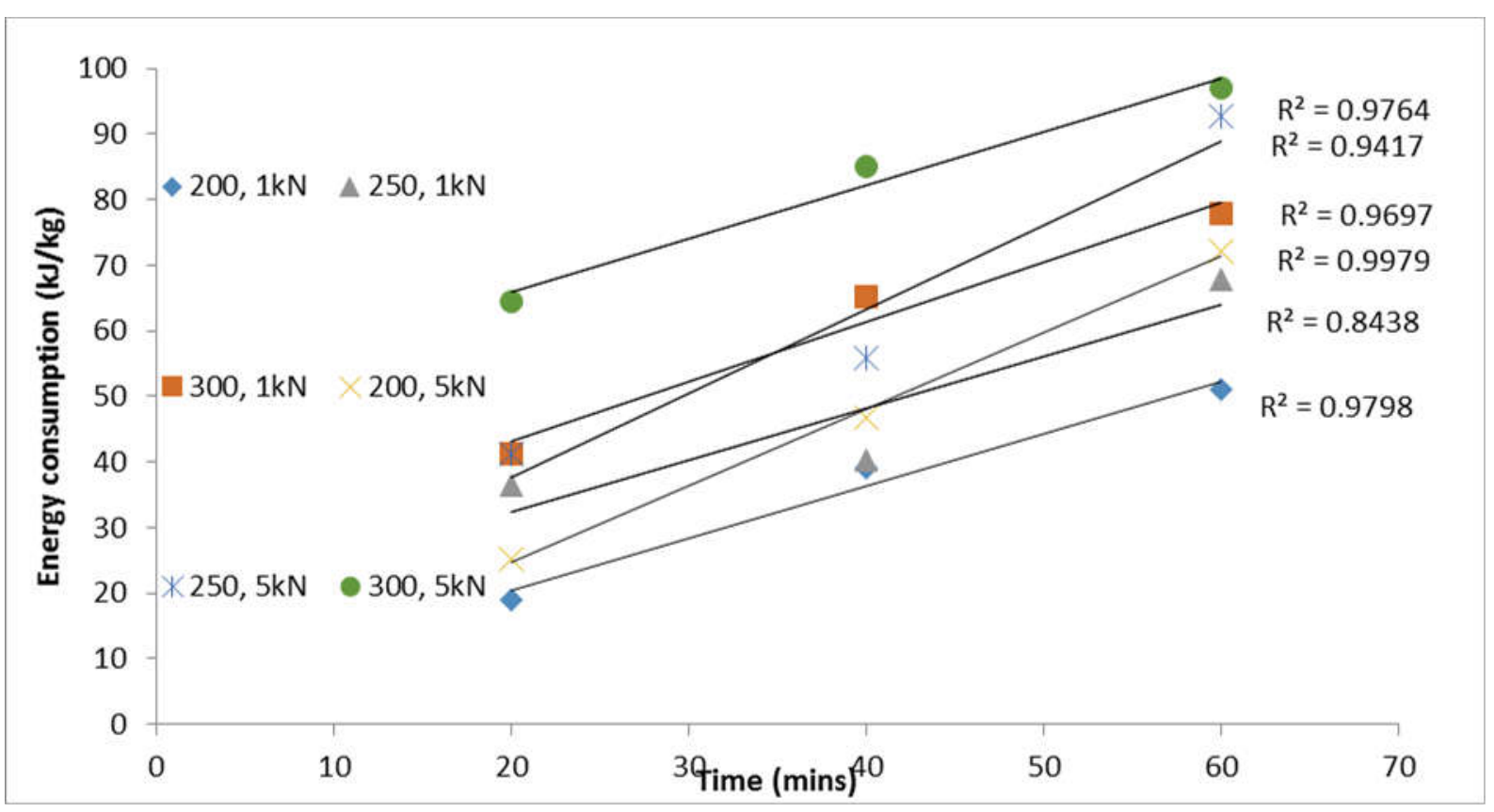

Fig.2b. Effect of energy consumption torrified EFB pellets

\subsection{Pellet Density}

Fig. 3a shows at the same force, the density rate decreased with increasing of particle size of EFB. The results from this study agreed well with the previous work as done by [7]. They found that the pellets made from lower particle size exhibited higher density for all biomass. The highest density of raw EFB pellet is is $907 \mathrm{kgm}^{3}$, while the lowest density of raw pellet is $623 \mathrm{kgm}^{3}$. In the past research, the higher compaction pressure or higher die temperature is required to increase the density of torrified pellets. The trend data analysis [12] shows the 
density of torrefied EFB pellets in Fig. $3 b$ decreased with increasing of degree of torrefaction temperature at the same residence time. As shown in the previous the reason why decreasing of pellet density is mainly related to the loss of chemically bonded water and low-melting point compounds which act as a binding agent when softened at $100^{\circ} \mathrm{C}$. In previous research, density of torrefied EFB pellets must be lower than raw EFB pellets due to loss of chemically bonded water and low melting point compounds during torrefaction [4]. However, the result shows the highest density of torrefied EFB pellet is $974 \mathrm{~kg} / \mathrm{m}^{3}$, while the lowest density of torrefied EFB pellet is $574 \mathrm{~kg} / \mathrm{m}^{3}$. For comparison, the torrefied sample shows the low density compared with raw sample.

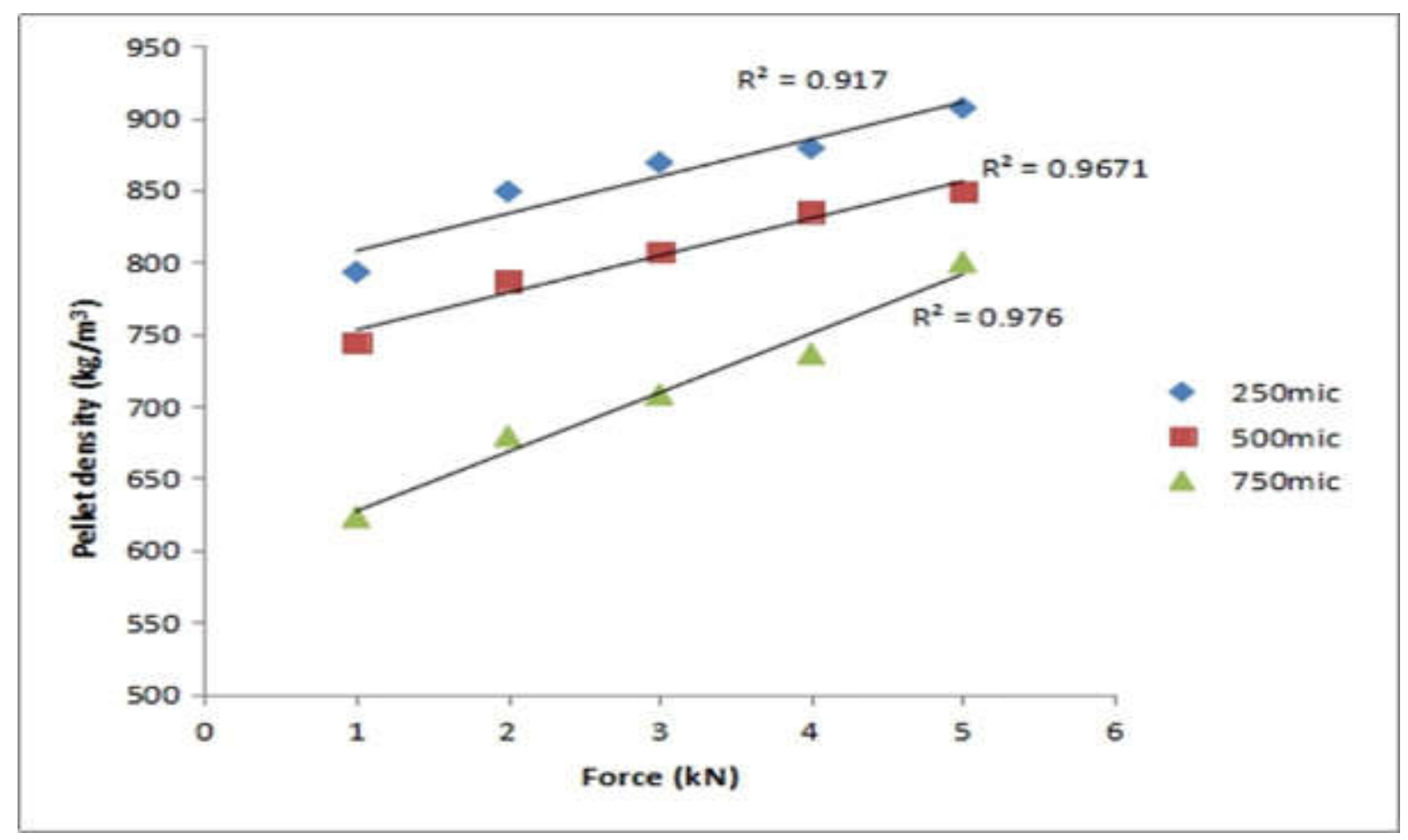

Fig.3a. Density of raw EFB pellets 


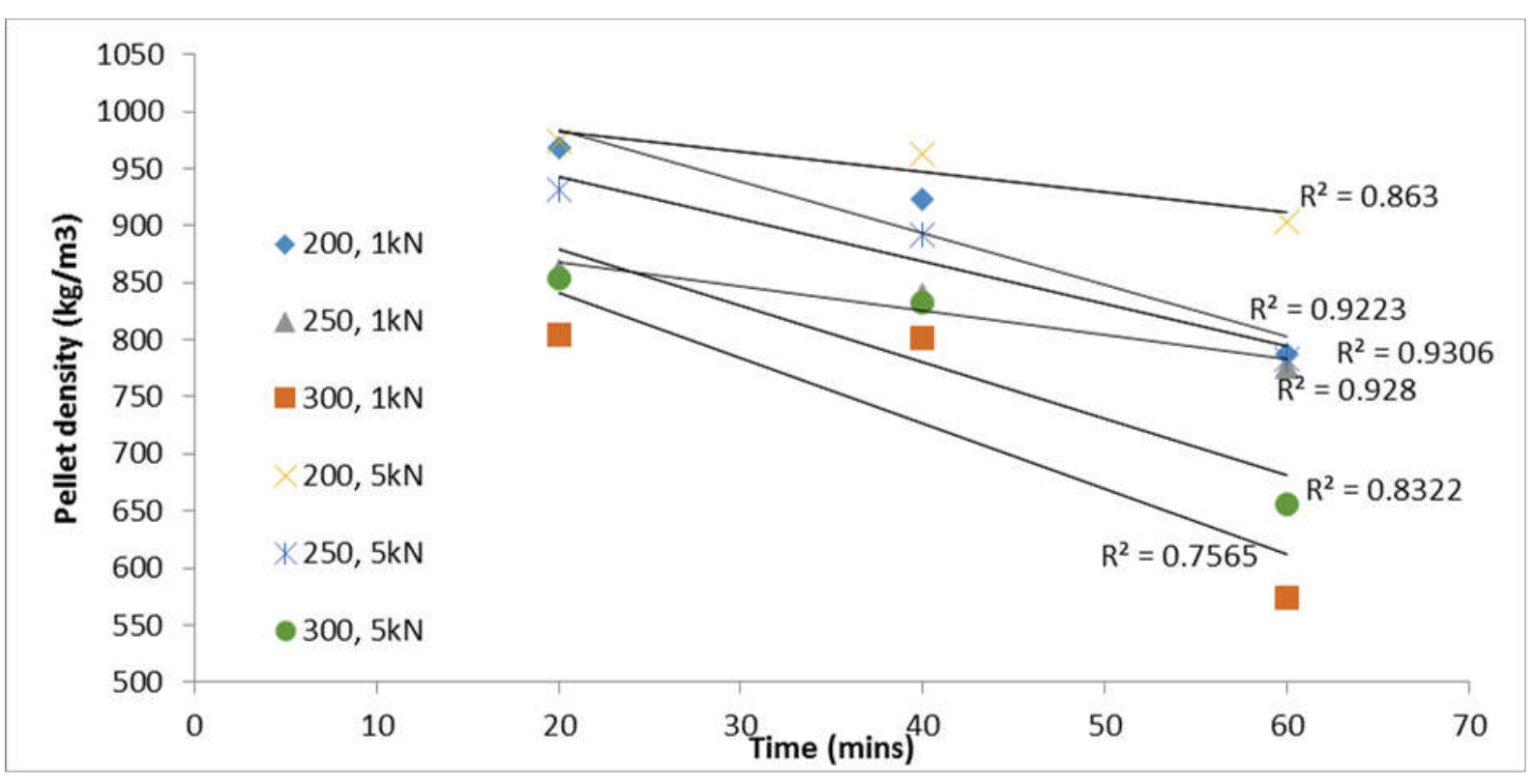

Fig.3b. Density of torrefied EFB pellet

\subsection{Moisture Adsorption}

Moisture adsorption by dry the pellets at $30^{\circ} \mathrm{C}$ in oven for 2 hours was measured, with the average results shown in Fig. $4 \mathrm{a}$ and $\mathrm{b}$. It is seen that the moisture adsorption capacity of EFB decreased significantly after torrefaction. Fig. 4a shows at the same sizes the water adsorption rate decreased with the increasing of force. The result shows the high moisture content of raw sample at $250 \mathrm{mic}$ with force $1 \mathrm{kN}$ which is $10.38 \mathrm{wt} \%$ but as shown in previous research [8], the high moisture content above optimum it gives negative effect on pellet density. Meanwhile, the low moisture content of raw sample at 750 mic with force $5 \mathrm{kN}$ which is 3.57 wt $\%$. Fig. $4 \mathrm{~b}$ also shows that at the same degree of residence time, the water adsorption rate decreased only slightly with increasing the torrefaction temperature, likely associated with the slight difference in the structure and composition of torrefied biomass [13]. The result shows the high moisture content of torrefied sample at $200^{\circ} \mathrm{C}$ with the residence time $20 \mathrm{~min}$ and force $1 \mathrm{kN}$ which is $5.91 \mathrm{wt} \%$, while the low moisture content at $300^{\circ} \mathrm{C}$ with the residence time $60 \mathrm{~min}$ and force at $5 \mathrm{kN}$ which is $0.09 \mathrm{wt} \%$. For comparison, the moisture adsorption of torrefied sample is lower than raw sample and as shown in previous research [3], the advantages of torrefaction includes higher calorific value or energy density, lower moisture content and better grinding. 


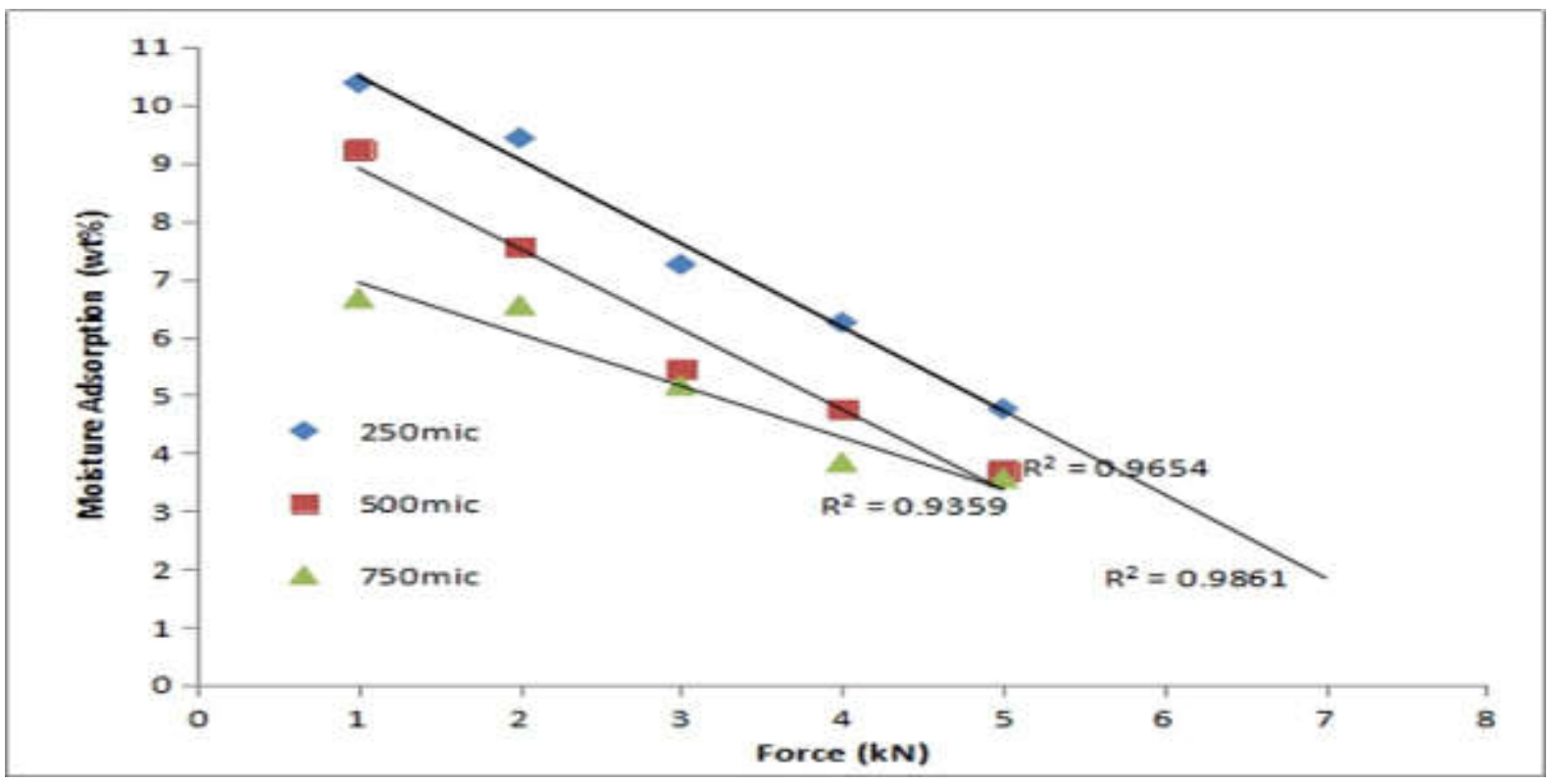

Fig.4a. Effect of weight loss on moisture adsorption raw EFB pellets

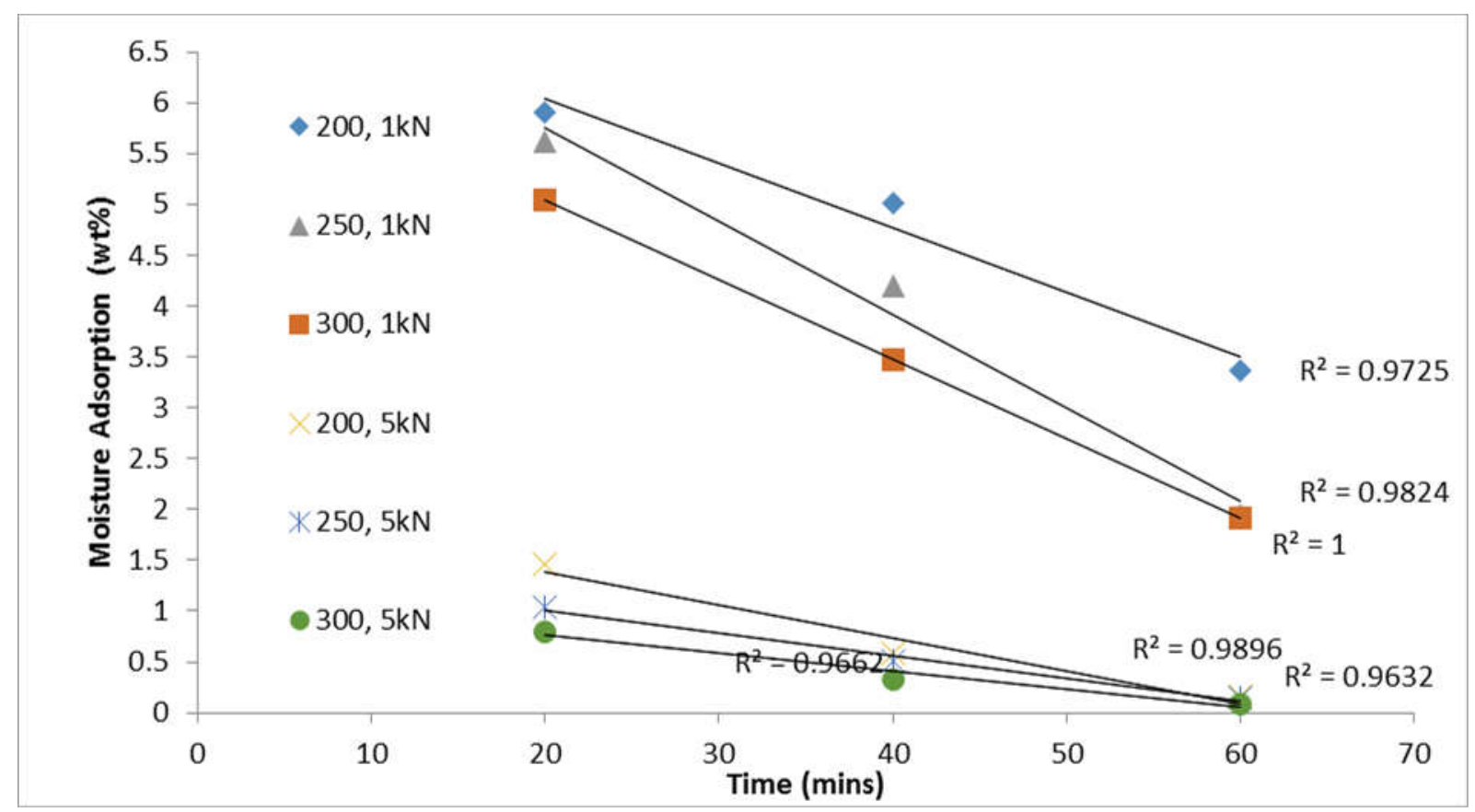

Fig.4b. Effect of weight loss on moisture adsorption torrified EFB pellets

\section{CONCLUSION}

The pelletization process of raw and torrefied EFB produced from Universal Testing Machine (UTM) by single pellet press (SPP) and the compression testing was used to identify the energy consumption and pellet properties. Energy consumption of torrified sample were significantly higher than raw sample at the same pelleting condition. The density of torrefied pellet was higher than raw pellet, while the torrefied pellet density decreased with increasing 
degree of torrefaction temperature and residence time. The hardness of pellet was reduced in the torrefaction process, while the hardness of pellets increased with the increasing of torrefaction but for the increasing residence time, the hardness becomes decreased. However, the moisture adsorption of torrefied pellet was lower than pellet from raw sample, while the moisture adsorption of torrefied pellets increased with increasing the severity of torrefaction.

\section{ACKNOWLEDGEMENTS}

The authors acknowledge that this work was financially supported by the Ministry of Higher Education Malaysia throughout the Research Acculturation Grant Scheme (R/ RAGS/ A08.00/ 01080A/ 001/2015/000211).

\section{REFERENCES}

[1] Adrian P, Gonzalez R, Saloni D, Denig J. Technical and economic assessment for the production of torrefied ligno-cellulosic biomass pellets in the US. Energy Conversion and Management, 2013, 66:153-164

[2] Aziz M A. Characterization of oil palm biomass as feed for torrefaction process. In IEEE National Postgraduate Conference, 2011, pp. 1-6

[3] Na B I, Kim Y H, Lim W S, Lee S M, Lee H W, Lee J W. Torrefaction of oil palm mesocarp fiber and their effect on. Biomass and Bioenergy, 2013, 52:159-165

[4] Li H, Liu X, Legros R, Bi X T, Lim C J, Sokhansanj S. Pelletization of torrefied sawdust and properties of torrefied pellets. Applied Energy, 2012, 93:680-685

[5] McNamee P, Adams P W, McManus M C, Dooley B, Darvell L I, Williams A, Jones J M. An assessment of the torrefaction of North American pine and life cycle greenhouse gas emissions. Energy Conversion and Management, 2016, 113:177-188

[6] Stelte W, Clemons C, Holm J K, Sanadi A R, Ahrenfeldt J, Shang L, Henriksen U B. Pelletizing properties of torrefied spruce. Biomass Bioenergy, 2011, 35(11):4690-4698

[7] Mościcki K J, Niedźwiecki Ł, Owczarek P, Wnukowski M. Commoditization of biomass: Dry torrefaction and pelletization-A review. Journal of Power Technologies, 2014, 94(4):233-249 
[8] Puig A M, Shang L, Sárossy Z, Ahrenfeldt J, Henriksen U B. From a single pellet press to a bench scale pellet mill-Pelletizing six. Fuel Processing Technology, 2016, 142:27-33

[9] Wang C, Peng J, Li H, Bi X T, Legros R, Lim C J, Sokhansanj S. Oxidative torrefaction of biomass residues and densification of torrefied sawdust to pellets. Bioresource Technology, 2013, 127:318-325.

[10] Muhammad I A, Mohd S M R, Shahril N M S, Mazlan M, Zairi I R, Mohd H M A. Preliminary study of microwave irradiation towards oil palm empty fruit bunches biomass. Journal of Tropical Resources and Sustainable Science, 2016, 8(1):133-137

[11] Mazlan M, Mohd H M A, Muhammad A S, Mohamad B A B, Mohamad N M, Muhammad I A, Nik A A N Y, Mohammad K A A R, Zairi I R. CFD simulation using wood (cengal and meranti) to improve cooling effect for Malaysia green building. ARPN Journal of Engineering and Applied Sciences, 2015, 10(20):9462-9467

[12] Mohd N K, Moumen I, Muhammad I A, Zairi I R. Computational analysis of air intake system for internal combustion engine in presence of acoustic resonator. ARPN Journal of Engineering and Applied Sciences, 2015, 10(20):9468-9475

[13] Muhammad I A, Zainal A Z A, Shahril N M S, Mazlan M, Zairi I R, Mohd S M R, Mohammad K A A R, Mohd H M A. Performance and carbon efficiency analysis of biomass via stratified gasifier. ARPN Journal of Engineering and Applied Sciences, 2015, 10(20):9533-9537

\section{How to cite this article:}

Ahmad MI, Jusoh WNKW, Rizman ZI, Rasat MSM, Alauddin ZAZ, Soid SNM, Aziz MSA, Mohamed M, Amin MFM.. Effect of torrefaction on oil palm empty fruit bunch pelletization. J. Fundam. Appl. Sci., 2017, 9(3S), 955-968. 